\title{
Comments on Duration of Contract and Precautionary Measures
}

\section{Martin Schauer}

Published online: 22 August 2008

(C) ERA 2008

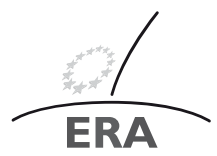

EUROPÄISCHE RECHTSAKADEMIE ACADEMY OF EUROPEAN LAW ACADEMIE DE DROIT EUROPEEN ACAOEME DE DROH TUROPEEN TRIER - TREVES - TREVIRI

\section{Duration of contract}

\subsection{Introductory remarks}

In general, insurance contracts are long-term contracts. This may be an advantage for both parties. If the contract is concluded for a period of several years, the insurer saves the costs of frequent renewals of said contract. This might lead to a decrease of the premium from which the policyholder benefits as well. Furthermore, the risk of being insured in most cases exists for a longer time. This is another and even more important reason why the policyholder might be interested in a contract which does not come to an end after some months or even some years.

On the other hand, long-term contracts can create disadvantages for both parties. The insurer might wish to cancel the contractual relations to the policyholder if the risk turns out to be larger than expected, or if the insurer is suspicious that the policyholder has not fulfilled the disclosure obligations but cannot prove it. The policyholder might wish to get out of the contract because he thinks he does not need insurance cover any longer or simply wants to turn to another insurer who offers better conditions.

These observations lead to the conclusion that both parties, depending on the case, sometimes might be interested in a stable and long-term relationship, and sometimes in short-term relations, or in a contract which can be terminated easily. From that

Prof. Dr. Martin Schauer $(\bowtie)$

University of Vienna, Civil Law Institute

Schottenbastei 10-16, 1010 Vienna, Austria

e-mail: martin.schauer@univie.ac.at

This paper is the written version of the presentation given by the author at the conference European Insurance Contract Law and the Common Frame of Reference (CFR), organised by ERA and the Joint Network on European Private Law in Trier on 21-22 January 2008. 
point of view, the question which needs to be answered by any legislation is not for which period of time an insurance contract may be concluded but if, by whom, and for what reasons it may be cancelled by one of the parties.

As the fundamental comparative study edited by Jürgen Basedow and Till Fock has shown, legislation in the Member States generally follows one of two possible solutions. ${ }^{1}$ The first one is that no provision is made for the permissible duration of the contract. So the contract may be concluded for any number of years which the parties agree upon within the limits of good faith and fair dealing. At the same time, a right to terminate the contract is given to the parties if the contract has lasted for a minimum time which may be one, three, or five years. This concept has basically been adopted in French law. German law is based on the same concept, although pursuant to the new Insurance Contract Act from 2007, the right to a premature cancellation of the contract is granted only to the insured party. Austrian law is even more restrictive because only a policyholder who is a consumer may terminate the contract before the time agreed upon in the contract. The second solution is based on the idea that the insurance contract should be limited to a one-year period. However, since both parties might be interested in the continuation of the contract, in some jurisdictions, law provides the prolongation of the contract unless notice is given to the other party. In other jurisdictions the prolongation of the contract may be agreed upon in the contract. This concept of one-year contracts can be found in Belgium, Sweden and Denmark.

On closer examination, the difference between the two concepts is not as large as it might seem. Basically, it is merely a question of legal construction. If a contract is concluded for a certain number of years, it can be terminated by one of the parties prematurely. If the contract is restricted to a short period of time by law, it will be renewed unless one party gives notice to the other one. If the renewal is considered to be a continuation of the existing contract and not a conclusion of a new contract, there is no difference between both ways shown. The reason for this is that in the case of continuation no further precontractual obligations, especially obligations of informations, have to be fulfilled by the parties. Furthermore, the next premium due will be considered a subsequent premium and not a first premium.

\subsection{Acquis communautaire}

The duration of an insurance contract has been in the focus of European Community law even in the past. In the proposal for a council directive on the coordination of laws, regulation and administrative provisions relating to insurance contracts of 1979, which may be considered the first attempt to harmonize insurance contract law within the Community, no maximum duration of the contract was provided. ${ }^{2}$ It was laid down that the insured party should be entitled to terminate the contract by the end of the third year and each of the following years if the contract was concluded for a longer period of time. One can clearly see that this provision is based on the first concept as described above. However, in the amended version of the proposal

\footnotetext{
1) Basedow/Fock [1], p. 123 et seq.

2) Art. 10 (3) c of the proposal for a Council Directive on the coordination of laws, regulations and administrative provisions relating to insurance contracts, OJ C 190, 28.7.1979, p. 2 et seq.
} 
of 1980, the right of the insured party to terminate the contract was weakened. The insured party should be entitled to terminate a long term contract after the third and each of the following years unless the premium was agreed upon for a certain period of the contract. ${ }^{3}$ Since these proposals have never been adopted by the Community legislation none of the provisions mentioned above became effective.

The block exemption for the insurance sector from 2003 provides that in standard policy conditions, having been jointly established and distributed by the insurance industry, a contract period of no more than three years may be imposed. ${ }^{4}$ A similar provision had been contained in the older block exemption regulation from $1992 .{ }^{5}$ However, this regulation has effect only with regard to competition law. If, in such standard policy terms, a contract period of more than three years were imposed, the exemption from Art 81 (3) of the Treaty would not be applicable. The regulation is not binding for the legislation of the Member States in the field of insurance contract law. Furthermore, it does not prevent the parties from an agreement on the duration of the contract of more than three years even if it is laid down in the standard policy terms of the insurer.

\subsection{Common Frame of Reference}

\subsubsection{General provisions}

\subsubsection{Termination of the contract without specific reasons}

\subsection{Introduction}

The message that can be found in the Common Frame of Reference in general is quite unambiguous: The duration of insurance contracts shall be one year. After the one-year period, the contract will be prolonged unless the insurer or the policyholder gives written notice to the other party (Art 2:601 and 2:602). This comes close to a contract, which was concluded for an indefinite period of time but may be terminated by the end of each year. Furthermore, these provisions show clearly that the CFR is based on the second concept, presented above. The reason why this concept was chosen may be found in Jürgen Basedow's and Till Fock's comparative study which was mentioned above. In their opinion, the concept of one-year contracts should prevail for reasons of clarity and unambiguity. Furthermore, it does not require complicated provisions about the termination of the contract. ${ }^{6}$ In general, one may agree with this concept. Nevertheless, it should be noticed that the provisions for avoiding the prolongation of the contract by giving notice to the other party are not so much different from the provisions for the termination of a long-term contract.

\footnotetext{
3) Art. 10 (3) $\mathrm{c}$ of the amendment of the proposal for a Council Directive on the coordination of laws, regulations and adminstrative provisions relating to insurance contracts (COM/80/854 final), OJ C 355, 31.12.1980, p. 30 et seq.

4) Art. 6, para. 1, f.of the Commission Regulation (EC) No 358/2003 of 27 February 2003 on the application of Article 81 (3) of the Treaty to certain categories of agreements, decisions and concerted practices in the insurance sector, OJ L 53, 28.2.2003, p. 53 et seq.

5) Art. 7, para. 1, g of the Commission Regulation (EEC) No 3932/92 of 21 December 1992 on the application of Article 85 (3) of the Treaty to certain categories of agreements, decisions and concerted practices in the insurance sector, OJ L 398, 31.12.1992, p. 7 et seq.

6) Basedow/Fock [1], p. 126.
} 


\subsection{Mandatory or default rules?}

If one takes a closer look some questions arise. The first one deals with the nature of the provisions as mandatory or as default rules. Pursuant to Art 2:601 (1), second sentence, parties may agree on a different period if indicated by the nature of the risk. So it seems that the one-year period has a partly mandatory character because any deviation, which the parties agreed upon in the contract, must be justified by the nature of the risk. This restriction may be considered unsatisfactory because in each case of a contractual deviation it is disputable if it was indicated by the nature of the risk.

Apart from that, one may doubt whether the provision about the duration of the contract should be mandatory at all. The insurer might accept a contractual relationship of more than one year based on Art 1:103 (2) which allows derogation from the provisions of the principles as long as such derogation is not to the detriment of the policyholder, the insured, or beneficiary. Why should the policyholder not be free to do so if he is not a consumer? For some policyholders a solution can be found in Art 1:103 (2) which permits the derogation of any kind of provision for certain risks typically attached to businesses or if the policyholder is a large enterprise exceeding certain minimum criteria.

\subsection{Scope of application}

Secondly, some remarks about the scope of application seem appropriate. The oneyear duration does not apply to personal insurance (Art 2:601 (2)). This exemption seems quite convincing as far as life insurance and health insurance is concerned. Generally, both life and health insurance are long-term contracts, which serve a long-term purpose. By the means of life insurance the policyholder intends to secure the provisions for his or her old age or for his or her family. Health insurance shall offer cover when it is needed most which refers to the insured person's old age as well. When it comes to accident insurance one may doubt if the exemption from the one-year duration is justified. To give an example: According to Art 6:201, car insurance would be subject to the general provision, which restricts the duration of the contract to one year. On the accident insurance for the passengers, however, which might be entered into at the same time, the one-year principle would not apply. A conclusion might be to restrict the exemption from the one-year principle to life and health insurance.

\subsection{Prolongation of the contract}

Thirdly, the provisions about the prolongation of the contract deserve some attention. The term "prolongation" seems to indicate that the idea is not the conclusion of a new contract but the continuation of the existing one. As mentioned above, the consequence is that the pre-contractual duties do not have to be fulfilled again, and the next premium after the prolongation will be considered a subsequent premium and not a first premium. If this is the solution, which was intended, it deserves unconditional approval because it meets the expectations of the average policyholder. In general, the policyholder would not consider the prolongation of the contract as the conclusion of a new one and he would not consider it necessary to comply with the pre-contractual disclosure duties once more.

Both parties may avoid the prolongation. The insurer has to give written notice to the policyholder "stating the reasons" for his decision. It is not quite clear why he 
has to give any reasons at all. Two ways of interpretation are possible. The first one is that the insurer has to explain why he is not willing to prolong the contract and the courts may examine if those reasons may be considered sufficient to terminate the contract. If they were not found to be sufficient, then the insurer would be obliged to prolong the contract. This reading of Article 2:602 (1) a) would come close to a concept which allows the insurer to terminate the contract only for specific reasons. Secondly, the provision could also be read in a way that the insurer may rely on any reason for not prolonging the contract and no examination by courts is possible. This solution is supported by the wording of Article 2:602 (1) a) and seems to be what was intended when the PEICL were drafted. But if this assumption is correct, it does not seem quite clear why the insurer has to state any reasons at all. Is this really a matter of legal obligation or just a question of politeness?

The policyholder also may avoid the prolongation of the contract by giving notice to the other party. He must do so at the latest by the day the contract period expires or within one month after having received the insurer's premium invoice, whichever day is later. In the latter case, the one month period shall only start to run if it has been clearly stated on the invoice in bold print (Art 2:602 (1) b). Obviously, this shall be a warning to the policyholder that he has one month left to give notice to the insurer if he wants to avoid the prolongation of the contract. However, it is not quite clear why this provision applies only if the policyholder receives the premium invoice after the last day of the contract period. If the policyholder is to be informed of his right to avoid the prolongation of the contract and this is considered to be appropriate, this principle should be applied in all cases.

Furthermore, one may ask about the legal consequences, if the policyholder receives a premium invoice that does not inform about the one-month period or if he does not receive an invoice at all. The latter might be the case if the policyholder has authorized the insurer to withdraw the amount of the premium from his bank account. This is a payment method frequently used at least in Germany and in Austria. If there is no information about the one-month period or no invoice at all, one has to draw the conclusion that the said period of one month will not start to run. The policyholder then would never be time-barred to give notice to the insurer when he wants to avoid the prolongation of the contract even if the contract period has expired many months ago. This result seems unsatisfactory. So it may be asked if the obvious intention of the policyholder to continue the contract may be considered as an implied waiver of the right to avoid the prolongation of the contract by giving notice to the insurer. Since this question is left open in the PEICL the answer should be found in the Principles of European Contract Law or in the general principles, common to the laws of the Member States (Art 1:105).

\subsection{Alteration of terms and conditions}

Art 2:603 refers to the alteration of terms and conditions. It is laid down in this article that in an insurance contract, which is liable to prolongation, a clause that allows the insurer to alter the premium or any other term or condition of the contract shall be invalid unless certain conditions are met: The alteration must not take effect before the next prolongation. The insurer shall send written notice of alteration to the policyholder and the notice shall inform the policyholder about his right of termination and the consequences if this right is not exercised. This provision shall apply without 
prejudice to other requirements for the validity of alteration clauses. The legal consequence is that the alteration becomes valid if the policyholder does not react.

The purpose of this provision seems clear: The policyholder shall be aware of his right to terminate the contract if he is not willing to accept the changes of the contract. Taking this into consideration, one may ask why other legal requirements for the validity of alteration clauses must be fulfilled as well. If the policyholder may terminate the contract and if the insurer may terminate the contract as well, one might argue that any suggestions of alterations should be possible.

\subsubsection{Termination for specific reasons}

Several provisions can be found in the PEICL, which permit the termination of the contract for specific reasons. For instance, the insurer is allowed to terminate the contract if the first or subsequent premium is not paid (Art 5:103).

The parties of the contract might wish to terminate the contract after the insured event has occurred. The occurrence of the insured event is sometimes called "the moment of truth" "because honesty and reliability of the other party often emerge after the occurrence of the insured event.

The current version of the PEICL does not provide for a legal right to terminate the contract after the insured event has occurred. Nevertheless, the parties are authorized to agree upon such a right in the contract (Art 2:604). However, attention must be paid to some restrictions. A clause providing the right for termination of the contract is valid only if the right is granted to both parties. Since both parties might have a legitimate interest to terminate the contract this provision of equality seems convincing. Furthermore, a right for termination may not be provided for in personal insurance contracts. This is convincing as far as life insurance and health insurance is concerned. Again, it may be asked if this exemption really should be applied to accident insurance. Furthermore, both the provision for termination and the exercise of the right to terminate must be reasonable. ${ }^{8}$ Obviously, the right to terminate the contract is bound to legitimate reasons, which may be examined by courts. The idea behind this provision seems to be that one party should not take the occurrence of the insured event as an excuse to terminate the contract that had already become unwelcome for other reasons. On the other hand, if the other party disputed the termination of the contract for being unreasonable, a lengthy procedure before court might be required to come to a decision. During the time of the procedure it is uncertain if the contract is still valid which might be an unpleasant situation for both parties.

\subsubsection{Preliminary cover}

Specific provisions about the duration of the contract can be found in connection with the preliminary cover. There are two cases that have to be distinguished.

The first one is that the applicant for insurance is granted preliminary cover. If that is the case, the cover will end no sooner than at the time when the cover under the insurance contract is agreed to begin or at the time the applicant receives the notice

7) Weyers/Wandt [2], n. 719; see also Basedow/Fock [1], p. 129.

8) Cf. also Basedow/Fock [1], p. 129. 
from the insurer definitively rejecting the application (Art 2:403 (1)). This concept is quite convincing because the preliminary cover loses its purpose if the final contract has become effective or if it becomes clear that the conclusion of the final contract cannot be expected any longer. However, it is not quite clear when the preliminary cover ends if the final contract is concluded but the policyholder does not pay the first premium in time. If the purpose of Art 5:101 is taken into consideration according to which the policyholder shall receive a warning about the lack of cover and must be granted a period of two more weeks for payment, then it seems consistent that the preliminary cover does not end before the two week period has expired. Perhaps this should be said more clearly in Art 2:403 (1).

Since the preliminary cover ends only if the final contract has been concluded or the application has been rejected, the insurer obviously is not entitled to terminate the preliminary cover during negotiations. This solution seems rather restrictive. Why should the insurer not be permitted to terminate the preliminary cover by giving notice to the applicant some days or weeks before the termination of the preliminary cover becomes effective?

In the second case, the applicant is granted preliminary cover without applying for an insurance contract with the same insurer. That raises the question how to distinguish this kind of preliminary cover from a final contract. An insurance contract should be recognized as a preliminary cover only if an application for a final contract is made to another insurer at the same time. If there is such a preliminary cover of that kind, its duration may be shorter than the one year period as provided in Art 2:601. Any contractual duration seems possible. Furthermore, either party may cancel the preliminary cover giving two weeks notice. It seems that this right to cancellation applies only if the parties have not agreed on a certain time of duration of the preliminary cover.

\section{Precautionary measures}

There are three articles in the PEICL, which deal with the precautionary measures. Art 4:101 provides a definition of those measures. In Art 4:102 and 4:103 the legal consequences of non-compliance are laid down.

\subsection{Definition}

Art 4:101 describes a precautionary measure as "a clause, whether or not described as a condition precedent to the liability of the insurer, requiring the policyholder or the insured, before the insured event occurs, to perform or not be perform certain acts." Both the definition and the purpose of the provision seem quite clear: The risk shall not be aggravated by acts of the policyholder or the insured. Therefore, certain acts of those persons may be prohibited in the contract.

However, the definition raises some questions. The first one is how to draw the line between a precautionary measure and an exemption from the risk covered by the contract. The problem can be illustrated by the following example: A car insurance policy might have the clause: "The policyholder and the insured person are obliged not to use the car under the influence of alcohol or drugs." This may clearly be con- 
sidered a precautionary measure. Would things change if the wording of the contract was different: "Any accident, which is caused under the influence of alcohol or drugs is excluded from the insurance cover."?

Secondly, one may ask about the relationship between the precautionary measures and the causation of the loss by an intentional or reckless act of the policyholder or the insured as defined in Art 9:101. If the insured does not comply with the precautionary measures, can Art 9:101 be applied as well?

Both problems are well known in national law. Dozens of theories have been developed by legal scholarship, especially in Germany. These problems will have to be discussed with regard to the PEICL as well, and European solutions will have to be found.

\subsection{Sanctions for non-compliance}

If the policyholder or the insured does not comply with the precautionary measures, two legal consequences may apply. The first one is the insurer's right to terminate the contract and the second one is the discharge of the insurer's liability (Art 4:102 and $4: 103$ ). The wording of both provisions indicates that these sanctions apply only if they are defined in a clause of the contract. Furthermore, the insurer is entitled to terminate the contract if the policyholder or the insured has acted with intent to cause the loss or recklessly and with knowledge that the loss would probably result.

Regarding the discharge of the insurer's liability, the provisions are more specific. A full discharge may be granted to the insurer only if the policyholder's or the insured's act is based on the intention to cause the loss or on recklessness and the knowledge that the loss would probably occur. Even in that case, the policyholder or the insured may claim the insurance money to the extent that the loss was not caused by the act of non-compliance. From this wording the conclusion may be drawn that partial indemnity is possible. If part of the loss would also have occurred if the policyholder and the insured had complied with the precautionary measures, then the insurer remains liable for this part of the loss. If the act of non-compliance is based on ordinary negligence, the amount of the insurance money may be reduced if provided in a clear clause in the contract. One may assume that the reduction of the insurance money also applies only if and insofar the negligent act has caused the loss.

This concept, which seems to be influenced by Scandinavian law ${ }^{9}$ is convincing. It balances the interest of the insurer in keeping the risk low and the interest of the insured in not losing cover without fault in an appropriate way.

\section{Concluding remarks}

The PEICL may be a milestone in the development of a European insurance contract law. They are fed by the common knowledge and the ideas of justice, which can be found in the insurance contract laws of the Member States. The solutions that have been found with regard to the duration of the contract and to the precautionary measures reflect those ideas. The concepts in general are convincing. As this presentation

9) Cf. Basedow/Fock [1], p. 81 et seq. 
has shown, some questions concerning certain aspects may be raised which leaves ground for further discussion. But this lies within the nature of jurisprudence.

\section{References}

1. Basedow, J., Fock, T.: Rechtsvergleich, in: Basedow/Fock (eds.) Europäisches Versicherungsvertragsrecht I (2002) 1

2. Weyers, H.-L., Wandt, M.: Versicherungsvertragsrecht, $3^{\text {rd }}$ ed., Luchterhand (2003) 